\title{
The Change Management Strategy in the Private Sector Insurance Companies after Covid-19
}

\author{
Meshal Al Kahtani \\ Alkahtani.meshal@gmail.com \\ College of Business Administration, American University in the Emirates \\ Working at Dubai Media Incorporated as TV Presenter
}

\begin{abstract}
This study would discuss the concept of change management and organization development as well as discusses the strategies for the insurance industry private organizations to incorporate change within it. Moreover, the study would identify the changes that were incorporated by the organization during the different pandemic situations of the past and after COVID-19 pandemic. This research followed quantitative research method by collecting responses from 163 participant's non-random sample, who answered the questionnaire survey which was distributed to specific employees working in private insurance companies in Dubai from different level. The survey conducted by sending the link through email and via WhatsApp. The results showed that the private insurance companies applied different change strategy during COVID-19 and planning to implement more plans after pandemic to reach their goals and achieve the customer satisfactions in order to survive and compete others. The researcher conclude that the insurance private companies got increase in revenues in some services but in the other hand they struggle from some issues like others, however, some recommendations provided at the end of the report.
\end{abstract}

Keywords: change management practices, insurance industry, organizational success,

\section{Introduction}

The insurance industry regardless of the type of the insurance be it home, travel, motor, property, or health is based on managing risks. That is something that is taken into consideration from the prospecting stages of customers, quoting for them to administering the insurance policies. During each stage of the insurance business the elements of change are taken into consideration. Be it change of seasonality, markets, health trends, inflations prices, and/or historical records of clients. Hence, it is only logical that insurance companies put change management at the heart of everything they do from the company's establishment, to organizational development and to its sustainability and viability. Insurance industry apply change management as part of their strategy in order to ensure no business disruption and to ensure sustainability. It is embedded in the strategy design, strategies into actions (SIAs), and execution. Based on the goals desired to be achieved by these companies, they would first ensure an organization alignment, then determine the adequate change management approach to be followed. From there onwards, they would take into considerations the elements of people, process, systems, and communications to be established, changed and/or improved. This process involves usually the respective departments and different levels of staff depending on the size and the goal of the change. Nowadays, with the global pandemic of COVID-19, insurance companies and industries have been impacted like many of the other industries. Most insurance clients are now seeking the lowest cost possible policy in terms of premium and coverage for their staff, properties, motors, and have in some cases stopped buying insurance especially when it comes to travel insurance with all the travel bans. Motor insurances were impacted negatively in terms of sales as well, with all the lockdowns across the world, and given that people weren't able

The current issue and full text archive of this journal is available at www.jraspublications.org/index.php/JRAS/issue/archive Journal of Research in Administrative Sciences (JRAS) IX(I), 12-18, ISSN: 2664-2433 to drive, renew their cars registrations and either refrained from renewing their insurances, or settled for the lowest and cheapest options. Property insurances also saw a decline in sales given customers' focus on cost reductions, and given that many of business either downsized or reduced the number of the assets or closed entirely. Health insurance saw multiple trends yet still had customers' seeking cheaper options and coverage. Yet still believed that health insurance is key in such global pandemic era. The trend of teleconsultations (Telephonic Doctors) also boomed in health insurance companies and saw the highest demands in history despite the fact that such feature and service is available globally since the 1980s. This service became almost the number one desired service in the health insurance coverage of customers. The above trends per insurance type clearly defined how gigantic COVID-19 impact was on insurance companies. The insurance companies with a health line of business were definitely the ones lucky enough to sustain their businesses and avoid downsizing and even complete business closures. The change management strategy is very important to any organization, either to compete with others, or surviving during any unexpected situation.

\section{Statement of the problem}

The researcher trying to figure out how insurance private companies are dealing with the COVID-19 pandemic, and what type of change management method has been applied, when it was implemented, who has made decisions about change, and which departments have they focused on.

\section{Research objectives}

- To explore the effects of pandemic on private sectors.

- To learn about the change management strategies applied by private companies during COVID-19. 
- To make a comparison between large and small companies in terms of survival during COVID-19.

\section{Research question}

- How did insurance industry deal with the unexpected situation of a pandemic that affected their efficiency and strategy?

- How did the leadership expertise will affect to implement the change strategy in proper way?

\section{Significance of study}

I hope this study explains how insurance private companies should implement a change strategy very quickly after an unexpected situation occurs in the market, to maintain their position and maintain competitive advantages.

\section{Limitations of study}

The shortage of time was the main limitations, and the low number of respondents from insurance private company to the survey questionnaire.

\section{Research hypothesis}

H1 there exists positive relationship between Change management practices and Organizational culture.

H2 there exists positive relationship between Leadership Organizational Development expertise and Organizational culture. H3 there exists positive relationship between Organizational Success and Organizational culture.

H4 there exists positive relationship between Leadership Organizational Development expertise and Organizational success. H5 there exists positive relationship between Change management practices and Organizational success.

H6 Organizational Culture mediates the relationship between Change Management Practices and Organizational Success.

H7 Organizational Culture mediates the relationship between Leadership Organizational Development Expertise and Organizational Success

\section{Literature review}

According to (Al-Haddad \& Kotnour, 2015), change management could be regarded as the systematic approach through which, organizations achieve their goals or transform their business processes or brings changes in their operational framework. (Lines, Sullivan, Smithwick, \& Mischung, 2015), explained that change management involves bringing change within the organization through controlling the change, reducing the resistance forces for the change as well as helping other employees to adapt to the change. Further, (Pollack, 2015) opined that for using the change management process effectively, five key steps need to be considered in which the first step involves understand the reason behind the change and afterward establishing effective communication with the organization's stakeholder. Afterward, (Pollack, 2015) mentioned developing plans for the change implementation, implementing it, and lastly evaluating it for the continuous growth and development of the organization. Thus, (Pollack, 2015) deduce the relationship between implementing change and organization development and mentioned that effective change management brings organization development. After the gap identification in the literature review, first hypotheses of the study (H1: there exists positive relationship between Change management practices and Organizational culture) is proposed.

Change Management Practices

However, (Kress, et al., 2015) mention organization development involves the activities performed by its stakeholder to make the organization sustainable with the dynamic change of the market. Additionally, (Bartunek \& Woodman, 2015) elaborate the concept of organization development and mentioned that using this process, the organization tends to become more flexible as well as achieve its purpose through making innovative changes in infrastructure, and operations. (Bartunek \& Woodman, 2015) also mentioned that organization development provides its stakeholder with more opportunities to improve their performance and make their job role simplified and aligned. After the gap identification in the literature review, second hypotheses of the study $(\mathrm{H} 2$ : there exists positive relationship between leadership organizational development expertise and organizational culture) is proposed.

Organizational Sucess

According to (Jenkins, 2015), the driver involves for the change implementation for public and private organizations shares the same attributes that involve financial austerity along with customer expectation, incorporation of disruptive technology, and many more. (Hameed, Khan, Sabharwal, Arain, \& Hameed, 2019) elaborate that the difference in the legal status of the public and private organization acts as a key factor for the change in the approach in the process of change management. (Boll \& Lagemann, 2018), further explained that many stakeholders were involved within public sector company, while, the leader of the private sector companies are limited due to which, the private organization found it to be easy to implement change compare to the public sector. (Ziemba \& Obłąk, 2015) mentioned that the public sector mainly involves either the ad hoc team or the third party or external agency to implement change management within the organization. (Ziemba \& Obłąk, 2015) also states the public sector makes changes mostly in the required areas of the organization and follows either the topdown or bottom-down approach. On the other hand, (Asnan, Nordin, \& Othman, 2015) mentioned that the private sector is quick to implement change management because they maintain an in-house team for this process as well as they know the areas that need to be changed. After the gap identification in the literature review, third hypotheses of the study (H3: there exists positive relationship between Organizational Success and Organizational culture) is proposed.

\section{Leadership Organizational Development Expertise}

(Gagnon, et al., 2018) mentioned that organization in the past deals with four major pandemic situations. (Gagnon, et al., 2018) highlighted the $\mathrm{H} 1 \mathrm{~N} 1$ virus pandemic of 1918, H2N2 virus pandemic of 1957, H3N2 virus pandemic of 1968, and H1N1 pdm09 virus pandemic of 2009. (Saunders-Hastings \& Krewski, 2016) narrates that in the past pandemic situation, the organization was less likely to focus on bringing change within its operation due to lack of knowledge in science and medicine. Further, (Dini, 2018) mentioned that the organization starts to bring major changes in its working operation with the H1N1 pandemic of 2009. From (SHRM, 2015), it was known that as the symptoms of H1N1 were comparably same to the COVID-19, and due to this reason, in the past, the organization also maintained the hygiene of their employees within the working place. For instance, (Chung, 2015) mentioned that the airport authority of nations such as Singapore puts heavy emphasis and restriction on the transport of food products, plant and animal material without proper checking and analyzing. (Hellin, Krishna, Erenstein, \& Boeber, 2015) has further mentioned that many organizations provide instruction to their employees to not consume the meat of birds. (Smallman, 2015) also mentioned that during the $\mathrm{H} 1 \mathrm{~N} 1$ flu organization design effective plan to protect its employees from the flu that involves providing training to the employee to maintain hygiene, social distance and strictly instruct the sick employee to remain in the home without fearing of job loss. Additionally, (Huremović, 2019) highlighted that during the $\mathrm{H} 1 \mathrm{~N} 1$ pandemic situation, organization incorporates changes within the working time of their operation and divides the working hour into many shifts so that social distancing within the organization could be followed effectively. After the gap identification in the literature review, fifth hypotheses of the study (H5: there exists positive relationship between Change management practices and Organizational success) is proposed. 
The Change Management Strategy in the Private Sector Insurance Companies after Covid-19

\section{Meshal Al Kahtani}

\begin{tabular}{|l|l|l|l|}
\hline $\begin{array}{l}\text { Measuring } \\
\text { Variables }\end{array}$ & factor & code & items \\
\hline $\begin{array}{l}\text { Change } \\
\text { management } \\
\text { practices }\end{array}$ & independent & (CMP) & $\mathrm{Q}(1,2,3,4,5)$ \\
\hline $\begin{array}{l}\text { Organizational } \\
\text { success }\end{array}$ & dependent & (OS) & $\mathrm{Q}(6,7,8,9,10)$ \\
\hline $\begin{array}{l}\text { Leadership } \\
\text { Organizational } \\
\text { Development } \\
\text { Expertise }\end{array}$ & independent & (LODE) & $\mathrm{Q}(11,12,13)$ \\
\hline $\begin{array}{l}\text { Organizational } \\
\text { Culture }\end{array}$ & mediator & (OC) & $\mathrm{Q}(14,15,16)$ \\
\hline
\end{tabular}

Research Methodology

This research followed quantitative research method to reach the research objectives and answering researcher questions, and the data was collected by quantitative data methods using survey questionnaire. The sample method wasrandom sampling, and the sample size reached was 163 participants from insurance industry who answering the questionnaire. The survey questionnaire contained 19 questions, starting with demographic questions while the others using 5-point Likert scale. Normality and liability tests were using by SPSS to check some tests and correlations between variables. The following diagram showing the theoretical framework based on interrelationship of study variables: independent variable (change management practices, leadership organization development expertise), mediating variable (organizational culture), and dependent variable (organizational success).

Figure 1 theoretical framework

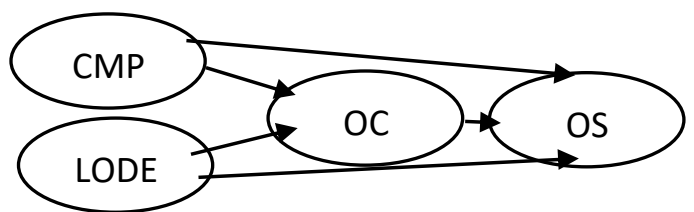

\section{Data Analysis and Results}

The researcher utilized SPSS to analyze the quantitative data by collecting 163 participants in the survey questionnaire, from different levels of private insurance organizations in UAE, following non-random sampling technique. Starting with sample characteristics the researchers ask the participants 3 demographic questions about their gender, age, and years of experience. The results show as in below charts, there are 60 females and 103 males of respondents, while the age was 6 respondents above 50 years old, 38 participants from $41-50$ years old, and 75 persons between 31 40 years old, while the remaining participants below 30 years old Most of employees participate in the survey had experience between 6-10 years, and 36 of them worked in this field from 11-15 years, while 26 participants had experience below 5 years, and the remaining 29 persons had more than 16 years working in insurance industry.

\begin{tabular}{|c|c|c|}
\hline $\begin{array}{c}\text { Table 1 } \\
\text { Gender }\end{array}$ & Frequency & $\begin{array}{c}\text { Cumulative } \\
\text { Percent }\end{array}$ \\
\hline female & 60 & 36.8 \\
Valid male & 103 & 100.0 \\
Total & 163 & \\
\hline \multicolumn{3}{|c|}{} \\
Table 2 & Frequency & Valid Percent \\
Age & 44 & 27.0 \\
20-30 & 75 & 46.0 \\
31-40 & 38 & 23.3 \\
$41-50$ & 6 & 3.7 \\
above 50 & 163 & 100.0 \\
Total &
\end{tabular}

\begin{tabular}{|c|c|c|c|}
\hline \multicolumn{2}{|c|}{$\begin{array}{c}\text { Table } 3 \\
\text { Years of experience }\end{array}$} & Frequency & Percent \\
\hline \multirow{5}{*}{ Valid } & $1-5$ years & 26 & 16.0 \\
\hline & $6-10$ years & 72 & 44.2 \\
\hline & 11-15 years & 36 & 22.1 \\
\hline & 16 years or above & 29 & 17.8 \\
\hline & Total & 163 & 100.0 \\
\hline
\end{tabular}

Table4 (Descriptives)

\begin{tabular}{|c|c|c|c|c|}
\hline & & & Statistic & Std. Error \\
\hline \multirow{13}{*}{$\begin{array}{l}\text { Leadership Organizational } \\
\text { Development Expertise1 }\end{array}$} & Mean & & 3.81 & .092 \\
\hline & \multirow{2}{*}{ 95\% Confidence Interval for Mean } & Lower Bound & 3.63 & \\
\hline & & Upper Bound & 3.99 & \\
\hline & \multicolumn{2}{|l|}{$5 \%$ Trimmed Mean } & 3.90 & \\
\hline & \multicolumn{2}{|l|}{ Median } & 4.00 & \\
\hline & \multicolumn{2}{|l|}{ Variance } & 1.390 & \\
\hline & \multicolumn{2}{|l|}{ Std. Deviation } & 1.179 & \\
\hline & \multicolumn{2}{|l|}{ Minimum } & 1 & \\
\hline & \multicolumn{2}{|l|}{ Maximum } & 5 & \\
\hline & \multicolumn{2}{|l|}{ Range } & 4 & \\
\hline & \multicolumn{2}{|l|}{ Interquartile Range } & 1 & \\
\hline & \multicolumn{2}{|l|}{ Skewness } & -1.089 & .190 \\
\hline & \multicolumn{2}{|l|}{ Kurtosis } & .330 & .378 \\
\hline \multirow{3}{*}{$\begin{array}{l}\text { Leadership Organizational } \\
\text { Development Expertise2 }\end{array}$} & \multicolumn{2}{|l|}{ Mean } & 3.95 & .080 \\
\hline & 95\% Confidence Interval for Mean & $\begin{array}{l}\text { Lower Bound } \\
\text { Upper Bound }\end{array}$ & $\begin{array}{l}3.79 \\
4.11\end{array}$ & \\
\hline & \multicolumn{2}{|l|}{$5 \%$ Trimmed Mean } & 4.03 & \\
\hline
\end{tabular}




\begin{tabular}{|c|c|c|c|}
\hline & Median & 4.00 & \\
\hline & Variance & 1.035 & \\
\hline & Std. Deviation & 1.017 & \\
\hline & Minimum & 1 & \\
\hline & Maximum & 5 & \\
\hline & Range & 4 & \\
\hline & Interquartile Range & 2 & \\
\hline & Skewness & -.863 & .190 \\
\hline & Kurtosis & .277 & .378 \\
\hline \multirow{12}{*}{$\begin{array}{l}\text { Leadership Organizational } \\
\text { Development Expertise3 }\end{array}$} & Mean & 4.12 & .076 \\
\hline & 95\% Confidence Interval for Mean & $\begin{array}{l}3.97 \\
4.27\end{array}$ & \\
\hline & $5 \%$ Trimmed Mean & 4.23 & \\
\hline & Median & 4.00 & \\
\hline & Variance & .931 & \\
\hline & Std. Deviation & .965 & \\
\hline & Minimum & 1 & \\
\hline & Maximum & 5 & \\
\hline & Range & 4 & \\
\hline & Interquartile Range & 1 & \\
\hline & Skewness & -1.531 & .190 \\
\hline & Kurtosis & 2.735 & .378 \\
\hline
\end{tabular}

About normality test like what we see in table 4 in Appendices for one variable which is Leadership Organizational Development Expertise shows there is normal distribution in terms of Std. Deviation and Skewness and Kurtosis.

Validity Test and reliability Test

The researcher tests the validity through two tests, face validity, and content validity which done by observing of survey questionnaire by our instructor, and one expertise working in insurance industry more than 15 years which was accepted by both of them.

Regarding reliability test the researcher performed it by testing the Cronbach Alpha for all variables, and the results was normal as follows:

The data based on five items of Change Management Practices shows reliable which $\mathrm{a}=.827$, and for the data based on five items of Organizational Success produce reliable which $\mathrm{a}=.864$, and the data based on three items of Leadership Organizational Development Expertise shows reliable which $\mathrm{a}=.826$, and the

\begin{tabular}{|l|c|c|}
\hline Items Name & items & $\begin{array}{c}\text { Cronbach } \\
\text { Alpha }\end{array}$ \\
\hline $\begin{array}{l}\text { Change Management } \\
\text { Practices CMP }\end{array}$ & 5 & 0.827 \\
\hline Organizational Success OS & 5 & 0.864 \\
\hline $\begin{array}{l}\text { Leadership Organizational } \\
\text { Development Expertise } \\
\text { LODE }\end{array}$ & 3 & 0.826 \\
\hline Organizational Culture OC & 3 & 0.716 \\
\hline All Items reliability test & 16 & 0.938 \\
\hline
\end{tabular}

data based on three items of Organizational Culture produce reliable which $\mathrm{a}=.716$. and the data based on all four variables show reliable which $\mathrm{a}=.938$

The descriptive statistics for compute variables

The table below shows in table 6 . how is data described by numbers, for examble the Std. Deviation shows close to zero which mean reilaible factors.

Table 6. (Descriptive Statistics)

\begin{tabular}{|c|c|c|c|c|c|c|c|c|c|}
\hline & $\mathrm{N}$ & Minimum & Maximum & Mean & Std. Deviation & \multicolumn{2}{|l|}{ Skewness } & \multicolumn{2}{|l|}{ Kurtosis } \\
\hline & Statistic & Statistic & Statistic & Statistic & Statistic & Statistic & Std. Error & Statistic & Std. Error \\
\hline CMP & 163 & 1.00 & 5.00 & 3.9411 & .80919 & -1.316 & .190 & 2.657 & .378 \\
\hline OS & 163 & 1.40 & 5.00 & 3.9423 & .77451 & -.832 & .190 & 1.402 & .378 \\
\hline LODE & 163 & 1.00 & 5.00 & 3.9591 & .91082 & -1.246 & .190 & 1.740 & .378 \\
\hline $\mathrm{OC}$ & 163 & 1.33 & 5.00 & 3.9959 & .89809 & -1.256 & .190 & 1.387 & .378 \\
\hline Gender & 163 & 1 & 2 & 1.63 & .484 & -.552 & .190 & -1.716 & .378 \\
\hline Age & 163 & 1 & 4 & 2.04 & .808 & .359 & .190 & -.462 & .378 \\
\hline Years of experiend & 163 & 1 & 4 & 2.42 & .961 & .302 & .190 & -.855 & .378 \\
\hline Valid N (listwise) & 163 & & & & & & & & \\
\hline
\end{tabular}

\begin{tabular}{|l|l|l|l|l|}
\hline \multicolumn{4}{|l|}{ Correlations } \\
\hline & CMP & OS & LODE & OC \\
\hline CMP & 1 & & & \\
\hline OS & $.778^{* *}$ & 1 & & \\
\hline LODE & $.704^{* *}$ & $.794^{* *}$ & 1 & \\
\hline OC & $.760^{* *}$ & $.678^{* *}$ & $.687^{* *}$ & 1 \\
\hline$* *$ Correlation is significant at the 0.01 level (2-tailed \\
\hline
\end{tabular}

Organizational Success shows significant relationship $(r=.778$, $\mathrm{p}<.05)$ with Change Management Practices.

Leadership Organization Development Expertise shows significant relationship $(r=.704, \mathrm{p}<.05)$ with Change Management Practices, and significance relationship $(r=.794$, $\mathrm{p}<.05)$ with organizational success.

Organizational culture shows significant relationship $(r=.760$, $\mathrm{p}<.05)$ with Change Management Practices, and significance relationship $(r=.678, \mathrm{p}<.05)$ with organizational success, and 
significance relationship $(\mathrm{r}=.687, \mathrm{p}<.05)$ with Leadership organization development expertise.

Hypothesis Test:

\begin{tabular}{|cc|c|c|c|c|c|}
\hline \multirow{2}{*}{ Model } & \multicolumn{2}{|c|}{ Unstandardized Coefficients } & $\begin{array}{c}\text { Standardized } \\
\text { Coefficients }\end{array}$ & \multirow{2}{*}{$\mathrm{t}$} & \multirow{2}{*}{ Sig. } \\
\cline { 3 - 5 } & & $\mathrm{B}$ & Std. Error & Beta & & \\
\hline \multirow{3}{*}{1 (Constan } & .390 & .236 & & 1.654 & .100 \\
& CMP & .586 & .088 & .528 & 6.643 & .000 \\
& LODE & .275 & .081 & .279 & 3.392 & .001 \\
& OS & .053 & .108 & .046 & .492 & .624 \\
\hline
\end{tabular}

a. Dependent Variable: $\mathrm{OC}$

$58.6 \%$ variation in $\mathrm{OC}$ is explained by CMP which is significant, CMP produced results $(\mathrm{B}=.586, \mathrm{P}<.05)$ indicating the acceptance of the first hypothesis (there exists positive relationship between Change management practices and Organizational culture) and $27.5 \%$ variation in OC is explained by LODE which significant, LODE produced results $(\mathrm{B}=.275$, $\mathrm{P}<.05$ ) indicating the acceptance of the second hypothesis (there exists positive relationship between Leadership Organizational Development Expertise and Organizational culture)..05\% variation in $\mathrm{OC}$ is explained by $\mathrm{OS}$ which mean it is not significant, OS produced results $(\mathrm{B}=.053, \mathrm{P}>.05)$ indicating rejecting third hypothesis (there exists positive relationship between Organizational Success and Organizational culture).

Coefficients $^{\mathrm{a}}$

\begin{tabular}{|ll|c|c|c|c|c|}
\hline \multirow{2}{*}{ Model } & & \multicolumn{2}{|c|}{ Unstandardized Coefficients } & $\begin{array}{c}\text { Standardized } \\
\text { Coefficients }\end{array}$ & \multirow{2}{*}{$\mathrm{t}$} & \multirow{2}{*}{ Sig. } \\
\cline { 3 - 5 } & & $\mathrm{B}$ & Std. Error & Beta & & \\
\hline & (Constan & .660 & .165 & & 4.006 & .000 \\
& CMP & .415 & .056 & .434 & 7.444 & .000 \\
& LODE & .416 & .050 & .489 & 8.388 & .000 \\
\hline
\end{tabular}

a. Dependent Variable: OS

$41.6 \%$ variation in OS is explained by LODE which is significant, LODE produced results $(\mathrm{B}=.416, \mathrm{P}<.05)$ indicating the acceptance of the fourth hypothesis (there exists positive relationship between Leadership Organizational Development Expertise and Organizational success). $41.5 \%$ variation in OS is explained by CMP which is significant, CMP produced results (B $=.415, \mathrm{P}<.05)$ indicating the acceptance of the fifth hypothesis (there exists positive relationship between Change Management Practices and Organizational Success). See details in the Appendices.

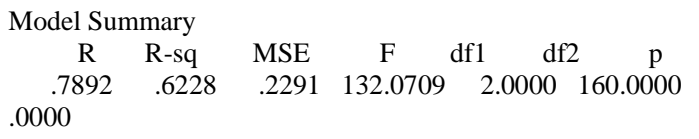

\begin{tabular}{|c|c|c|c|c|c|}
\hline \multicolumn{6}{|l|}{ Model } \\
\hline & coeff & se & $\mathrm{t}$ & LLCI & ULCI \\
\hline $\begin{array}{l}\text { constant } \\
1.2682\end{array}$ & .8892 & .1919 & 4.6330 & .0000 & .5101 \\
\hline $\begin{array}{l}\text { CMP } \\
.7363\end{array}$ & .5951 & .0715 & 8.3286 & .0000 & .4540 \\
\hline $\begin{array}{l}\text { OC } \\
.3042\end{array}$ & .1771 & .0644 & 2.7505 & .0066 & .0499 \\
\hline
\end{tabular}

****************** DIRECT AND INDIRECT EFFECTS

OF X ON Y ******************

Direct effect of $\mathrm{X}$ on $\mathrm{Y}$

$\begin{array}{llllll}\text { Effect } & \mathrm{s} & \mathrm{t} & \mathrm{p} & \text { LLCI } & \text { ULCI }\end{array}$

$\begin{array}{llllll}.5951 & .0715 & 8.3286 & .0000 & .4540 & .7363\end{array}$

Indirect effect(s) of $\mathrm{X}$ on $\mathrm{Y}$ :

Effect BootSE BootLLCI BootULCI

$\begin{array}{lllll}\text { OC } & .1493 & .0449 & .0633 & .2412\end{array}$

The indirect effect of CMP on OS (.1493) is positive and partially significant: null of zero lying between $(.0633, .2412)$ indicates that there is partially mediation so the sixth hypothesis (Organizational Culture mediates the relationship between Change Management Practices and Organizational Success) is partially accepted. See details in the Appendices. \begin{tabular}{lllllll}
\multicolumn{3}{l}{ Model Summary } \\
$\mathrm{R}$ & $\mathrm{R}-\mathrm{sq}$ & $\mathrm{MSE}$ & $\mathrm{F}$ & $\mathrm{df} 1$ & $\mathrm{df} 2$ & $\mathrm{p}$ \\
.8147 & .6638 & .2042 & 157.9447 & 2.0000 & 160.0000 \\
.0000 & & & & & &
\end{tabular}

Model

\begin{tabular}{|c|c|c|c|c|c|}
\hline \multicolumn{2}{|c|}{ coeff } & se & $\mathrm{p}$ & LLCI & ULCI \\
\hline $\begin{array}{l}\text { constant } \\
1.3277\end{array}$ & .9845 & . 1737 & 5.6664 & .0000 & .6414 \\
\hline $\begin{array}{l}\text { LODE } \\
6348\end{array}$ & .5289 & .0536 & 9.8665 & .0000 & .4231 \\
\hline $\begin{array}{l}\text { OC } \\
3235\end{array}$ & . 2162 & . 0544 & 3.9758 & .0001 & . 1088 \\
\hline
\end{tabular}

$* * * * * * * * * * * * * * * * * *$ DIRECT AND INDIRECT EFFECTS

OF X ON Y *******************

Direct effect of $\mathrm{X}$ on $\mathrm{Y}$

Effect se $\mathrm{t} \quad \mathrm{p}$ LLCI ULCI

$\begin{array}{llllll}.5289 & .0536 & 9.8665 & .0000 & .4231 & .6348\end{array}$

Indirect effect(s) of $\mathrm{X}$ on $\mathrm{Y}$ :

Effect BootSE BootLLCI BootULCI

$\begin{array}{lllll}\text { OC } & .1463 & .0321 & .0839 & .2117\end{array}$

The indirect effect of LODE on OS (.1463) is positive and partially significant: null of zero lying between $(.0839, .2117)$ indicates that there is partially mediation so the seventh hypothesis (Organizational Culture mediates the relationship between Leadership Organizational Development Expertise and Organizational Success) is partially accepted. See details in the Appendices. 


\begin{tabular}{|c|l|l|}
\hline S. no & Hypothesis & Result \\
\hline 1 & $\begin{array}{l}\text { H1 there exists positive relationship between Change management practices and } \\
\text { Organizational culture. }\end{array}$ & Accepted and significant. \\
\hline 2 & $\begin{array}{l}\text { H2 there exists positive relationship between Leadership Organizational } \\
\text { Development expertise and Organizational culture. }\end{array}$ & Accepted and significant. \\
\hline 3 & $\begin{array}{l}\text { H3 there exists positive relationship between Organizational Success and } \\
\text { Organizational culture. }\end{array}$ & Rejected \\
\hline 4 & $\begin{array}{l}\text { H4 there exists positive relationship between Leadership Organizational } \\
\text { Development expertise and Organizational success. }\end{array}$ & Accepted and significant. \\
\hline 5 & $\begin{array}{l}\text { H5 there exists positive relationship between Change management practices and } \\
\text { Organizational success. }\end{array}$ & Accepted and significant. \\
\hline 6 & $\begin{array}{l}\text { H6 Organizational Culture mediates the relationship between Change Managemer } \\
\text { Practices and Organizational Success. }\end{array}$ & $\begin{array}{l}\text { Partially accepted and } \\
\text { positive significant. }\end{array}$ \\
\hline 7 & $\begin{array}{l}\text { H7 Organizational Culture mediates the relationship between Leadership } \\
\text { Organizational Development Expertise and Organizational Success. }\end{array}$ & $\begin{array}{l}\text { Partially accepted and } \\
\text { positive significant. }\end{array}$ \\
\hline
\end{tabular}

\section{Conclusions and recommendations}

The change management strategy is very important to any organization, either to compete with others, or surviving during any unexpected situation. It could be said that change management brings opportunity for the stakeholders and introduces innovative strategies within the organization so that organization could develop and reach its objective. Further, the study concludes that the insurance private companies, are affected by the same factors, yet they require different change management strategies to implement change. Moreover, the study mentioned that during the previous pandemic situation, many organizations incorporate effective and flexible changes through training and regulating their workforce. Some insurance companies had been increased their revenues from some kind of services because of COVID-19 pandemic which increase the demand for health and life insurance, while some services had declined because of such situation, which force them to implement different plans for change and redesign their strategies in order to develop organization and stay at proper position in the market. The change management was difficult because of unexpected situation, so their plans applied rapidly to survive and go for sustainability they are looking for. Some participants showed scores of unsatisfaction from their leaders who doesn't involve them in the making decision process which made them upset and not encouraged to be part of the change, while others mentioned that they got a lot of experience from the pandemic in terms of dealing with unexpected situations if it happened again. Customer centricity should be at the heart of everything an insurance company do. Insurance companies should become resilient to changes in the dynamics of markets, economy, and every aspect of the business to develop, sustain and become viable.

I recommend insurance company to be proactive and thinking for future to predict the situation and come out with some ideas which will benefit their customers. They have to involve their employees with the process of making decisions because they are at the field and they know what the client's needs. Some offers must be made to clients to fulfill their desires, especially those related to health needs. They should focus on digital which is the new world of commerce in insurance industry and many others. Also focus on health which is the key for any insurance company, and it is one of the biggest industries globally and it continuously changes as needs become. It is complex but worth the investment. Health, health, health insurance.

\section{References}

i. Al-Haddad, S., \& Kotnour, T. (2015). Integrating the organizational change literature: a model for successful change. Journal of organizational change management. Retrieved from http://www.cin.ufpe.br/ 1lfj/Emerald/Integrating\%20the\%20org anizational\%20change $\% 20$ literature $\% 20$ $\% 20$ a\%20model $\% 20$ for $\% 20$ successful\%20change.pdf ii. Asnan, R., Nordin, N., \& Othman, S. N. (2015). Managing change on lean implementation in service sector. Procedia-Social and Behavioral Sciences, 211, 313-319. Retrieved from https://www.sciencedirect.com/science/article/pii/S1877042815 05380X/pdf?md5=dc4543140ef53f4f2a042828e6d1b587\&pid= 1-s2.0-S187704281505380X-main.pdf

iii. Bartunek, J. M., \& Woodman, R. W. (2015). Beyond Lewin: Toward a temporal approximation of organization development and change. Retrieved from https://www.researchgate.net/profile/Jean_Bartunek/publication /271722643_Beyond_Lewin_Toward_a_Temporal_Approximat ion_of_Organization_Development_and_Change/links/552dbc8 c0cf2e089a3ad8192/Beyond-Lewin-Toward-a-TemporalApproximation-of-Organization-Develo

iv. Boll, C., \& Lagemann, A. (2018). The gender pay gap in the public and private sector in Germany-magnitude, evolution 20102014 and main drivers (No. 183). HWWI Research Paper. Retrieved from https://www.econstor.eu/bitstream/10419/182106/1/103043958 3.pdf

v. Chung, L. H. (2015). Impact of pandemic control over airport economics: Reconciling public health with airport business through a streamlined approach in pandemic control. Journal of Air Transport Management, 44, 42-53. Retrieved from https://www.ncbi.nlm.nih.gov/pmc/articles/PMC7148882/

vi. Cloutier, O., Felusiak, L. H., \& Pemberton-Jones, E. J. (2015). The Importance of Developing Strategies for Employee Retention. Journal of Leadership, Accountability \& Ethics, 12(2). Retrieved from http://www.m.www.nabusinesspress.com/JLAE/Pemberton-JonesEJ_Web12_2_.pdf

vii. Dini, G. T. (2018). Influenza vaccination in healthcare workers: A comprehensive critical appraisal of the literature. Human vaccines \& immunotherapeutics, 14(3), 772-789. Retrieved from https://www.tandfonline.com/doi/pdf/10.1080/21645515.2017.1 348442

viii. Gagnon, A., Acosta, E., Hallman, S., Bourbeau, R., Dillon, L. Y., Ouellette, N., \& ... Miller, M. S. (2018). Pandemic paradox: early life $\mathrm{H} 2 \mathrm{~N} 2$ pandemic influenza infection enhanced susceptibility to death during the $2009 \mathrm{H} 1 \mathrm{~N} 1$ pandemic. MBio, 9(1). Retrieved from https://mbio.asm.org/content/mbio/9/1/e02091-17.full.pdf

ix. Hameed, I., Khan, A. K., Sabharwal, M., Arain, G. A., \& Hameed, I. (2019). Managing successful change efforts in the public sector: An employee's readiness for change perspective. Review of Public Personnel Administration, 39(3), 398-421. Retrieved from https://www.researchgate.net/profile/Meghna_Sabharwal/public ation/319860317_Managing_Successful_Change_Efforts_in_th e_Public_Sector_An_Employee's_Readiness_for_Change_Pers pective/links/59c11490458515af305c520f/ManagingSuccessful-Change-Efforts-in-the-Pub

x. Hellin, J., Krishna, V., Erenstein, O., \& Boeber, C. (2015). India's poultry revolution: implications for its sustenance and the 
global poultry trade. International Food and Agribusiness Management Review, 18(1030-2016-83092), 151-164. Retrieved from

https://ageconsearch.umn.edu/record/207008/files/2014013411. pdf

xi. Huremović, D. (2019). Social distancing, quarantine, and isolation. In Psychiatry of Pandemics (pp. 85-94). Springer, Cham. Retrieved from https://www.researchgate.net/profile/Saeed_Ahmed46/publicati on/341446249_Psychiatry_of_Pandemics_A_Mental_Health_R esponse_to_Infection_Outbreak/links/5ec14cb3299bf1c09ac12e 8b/Psychiatry-of-Pandemics-A-Mental-Health-Response-toInfection-Outbreak.pdf\#page=

xii. Jenkins, M. (2015, April 15). Build Change Management Capability across Sectors. Retrieved from koganpage.com: https://www.koganpage.com/article/handle-change-effectivelyin-the-private-and-public-sector

xiii. Kress, H. G., Aldington, D., Alon, E., Coaccioli, S., Collett, B., Coluzzi, F., \& ... Mangas, A. C. (2015). A holistic approach to chronic pain management that involves all stakeholders: change is needed. Current medical research and opinion, 31(9), 1743-. Retrieved from https://www.tandfonline.com/doi/pdf/10.1185/03007995.2015.1 072088

xiv. Lines, B. C., Sullivan, K. T., Smithwick, J. B., \& Mischung, J. (2015). Overcoming resistance to change in engineering and construction: Change management factors for owner organizations. International Journal of Project Management, 33(5), 1170-1179. Retrieved from https://tarjomefa.com/wpcontent/uploads/2017/01/6008-English-TarjomeFa.pdf

xv. Pollack, J., \& Pollack, R. (2015). Using Kotter's eight stage process to manage an organisational change program: Presentation and practice. Systemic Practice and Action Research, 28(1), 51-66. Retrieved from https://opus.lib.uts.edu.au/bitstream/10453/30796/1/Pollack\%20 \%26\%20Pollack\%2C\%202014\%20-\%20prepublication\%20.pdf

xvi. Saunders-Hastings, P. R., \& Krewski, D. (2016). Reviewing the history of pandemic influenza: understanding patterns of emergence and transmission. Pathogens, 5(4), 66. Retrieved from https://www.mdpi.com/2076-0817/5/4/66/pdf

xvii. SHRM. (2015). Managing Through Flu and Other Epidemics in the Workplace. Retrieved from shrm.org: https://www.shrm.org/resourcesandtools/tools-andsamples/toolkits/pages/managingfluandepidemics.aspx

xviii. Smallman, S. (2015). Whom do you trust? Doubt and conspiracy theories in the 2009 influenza pandemic. Journal of International \& Global Studies. Retrieved from https://pdxscholar.library.pdx.edu/cgi/viewcontent.cgi?article=1 011\&context=is_fac

xix. Torfing, J., Sørensen, E., \& Røiseland, A. (2019). Transforming the public sector into an arena for co-creation: Barriers, drivers, benefits, and ways forward. Administration \& Society, 51(5), 795-825. Retrieved from http://centerforborgerdialog.dk/wpcontent/uploads/2017/12/R\%C3\%B8iseland-S\%C3\%B8rensenand-Torfing-on-cocreation-1.pdf

xx. van den Boogaard, L. (2018). I amSMARTerdam: Revaluating the Smart City concept through the world's most bottom-up Smart City. Retrieved from https://www.divaportal.org/smash/get/diva2:1231871/FULLTEXT02

xxi. Ziemba, E., \& Obłąk, I. (2015). Change management in information systems projects for public organizations in Poland. Interdisciplinary Journal of Information, Knowledge, and Management, 10, 47-62. Retrieved from http://www.ijikm.org/Volume10/IJIKMv10p047-

062Ziemba1527.pdf 